\title{
Quantification of Cell Nuclei Isolated from Hepatocytes by Cell Lysis with Nonionic Detergent in Citric Acid
}

\author{
Yoshifumi Horiuti, Motohiro Ogishima, Kazuo Yano, and Yuzo Shibuya \\ Research Laboratories, Toyo Jozo Co., Ltd., Mifuku, Ohito-cho, Tagata-gun, Shizuoka 410-23, Japan
}

Key words: quantification/hepatocyte/cell nuclei/detergent/nikkol BO-10TX

\begin{abstract}
$A B S T R A C T$. A method was developed for determining the number of nuclei of hepatocytes cultured on collagen gel using a nonionic detergent, Nikkol BO-10TX. The cells were recovered in a test tube after solubilizing the gel by incubating it with the detergent in $0.1 \mathrm{M}$ citric acid and then centrifuging the mixture. Nuclei were isolated from the cells with the same detergent solution and collected by centrifugation. The numbers of nuclei in cultures, scored with a hemocytometer or an electronic particle counter, were proportional to the lactate dehydrogenase activities of the cells. This method was also applicable for scoring the number of nuclei of hepatocytes cultured on collagen-coated plastic.
\end{abstract}

The number of cultured hepatocytes cannot be determined accurately by conventional methods such as counting detached cells after exposure to EDTA-trypsin mixture, because the cells readily aggregate and are fragile after detachment (1). Therefore, almost no linear relationships between numbers of cells and various parameters have been observed, and so in many studies on specific activities or growth of cultured hepatocytes, the amount of protein or DNA in cell lysates has been utilized instead of the number of cells. In some studies, hepatocyte nuclei in cultures have been quantified in an electronic particle counter after lysing the cells with $0.1 \%$ Triton $\mathrm{X}-100$ in $0.1 \mathrm{M}$ citric acid (2). But, this method gives numerically fewer nuclei compared with the number of the cells from which the nuclei were isolated, possibly because the detergent damages the nuclei to some extent and the damaged nuclei tend to aggregate partially during storage of the nucleus solution. Hence, we attempted to find a better detergent that was strong enough to lyse most of the cells without damaging their nuclei, and to develop a simple and improved assay procedure for quantification of hepatocytes cultured on collagen gel in serum-free medium. With the use of a $0.07 \%$ solution of the nonionic detergent Nik$\mathrm{kol} \mathrm{BO-10TX}$ in $0.1 \mathrm{M}$ citric acid (NCA), we found that the cell nuclei could be obtained quantitatively from either freshly isolated or cultured hepatocytes and stored for at least 2 days in $0.1 \mathrm{M}$ citric acid without any troublesome aggregation. This procedure is, therefore, useful for obtaining quantitative data on either

Abbreviations used: NCA, $0.07 \%$ Nikkol BO-10TX in $0.1 \mathrm{M}$ citric acid; $\alpha$ MEM, $\alpha$-modified Eagle's minimum essential medium; PBS, phosphate buffered saline; LDH, lactate dehydrogenase. cell survival or cell growth.

\section{MATERIALS AND METHODS}

Isolation of hepatocytes. Hepatocytes were isolated from adult male Wistar rats weighing about $200 \mathrm{~g}$ by perfusion of the liver in situ with collagenase essentially as described by Seglen (3) and suspended in $\alpha$-modified Eagle's minimum essential medium ( $\alpha \mathrm{MEM}$ ) supplemented with amphotericin B $(0.25 \mathrm{mg} / \mathrm{l})$, gentamycin $(60 \mathrm{mg} / \mathrm{l})$ and penicillin $\mathrm{G}(10$ units/1). Preparation of collagen gel-Collagen solution and gel were prepared from rat tail tendons by a modification (4) of the method originally described by Elsdale and Bard (5). The collagen fibers were washed with distilled water and then ethanol, and dried. A sample $(1 \mathrm{~g})$ was immersed in ethanol overnight for sterilizing, taken out and dissolved in sterile $0.1 \%$ acetic acid solution $(500 \mathrm{ml})$ with stirring for $5 \mathrm{~h}$ at $5^{\circ} \mathrm{C}$. The resulting collagen solution was centrifuged at $7,000 \times \mathrm{g}$ for $30 \mathrm{~min}$ at $5^{\circ} \mathrm{C}$ to remove insoluble material, stored for 1 week at $5^{\circ} \mathrm{C}$ and recentrifuged under the same conditions. The supernatant was used as a stock collagen solution. Just before use, it was diluted to $0.7 \mathrm{mg} / \mathrm{ml}$ with acetic acid solution and mixed with one-third volume of conc $(\times 4) \alpha$ MEM containing Hepes $(40 \mathrm{mM})$; the concentration of collagen was determined by measuring the absorbance at $230 \mathrm{~nm}$ with commercial rat tail collagen (Sigma) as a standard. The mixture was adjusted to about $\mathrm{pH} 7.4$ with $1 \mathrm{~N} \mathrm{NaOH}$ and kept on ice to prevent immediate gelation. Aliquots of the resulting collagen solution $(1 \mathrm{ml})$ were pipetted into plastic dishes (d: 35 $\mathrm{mm}$ ) and allowed to gel at $37^{\circ} \mathrm{C}$ for $30-60 \mathrm{~min}$ in a $\mathrm{CO}_{2}$ incubator. Culture of hepatocytes on collagen gel-A suspension of cells in various numbers in $\alpha \mathrm{MEM}(1 \mathrm{ml})$ was inoculated onto the gels and incubated for about $2 \mathrm{~h}$ in a $\mathrm{CO}_{2}$ incubator to allow cell attachment. The medium was then replaced by 
$\alpha$ MEM (1 ml) containing insulin $(0.1 \mu \mathrm{M})$, dexamethasone $(0.1 \mu \mathrm{M})$, ascorbate $(0.3 \mathrm{mM})$ and pyruvate $(10 \mathrm{mM})$, and the cells were cultured under $5 \% \mathrm{CO}_{2}$ in air at $37^{\circ} \mathrm{C}$. The medium was changed $24 \mathrm{~h}$ after plating.

Culture of hepatocytes on collagen-coated plastic. Culture dishes (d: $35 \mathrm{~mm}$ ) were covered with $1 \mathrm{ml}$ of collagen solution $(0.7 \mathrm{mg} / \mathrm{ml})$, allowed to stand for $5 \mathrm{~min}$ at room temperature, drained and washed twice with phosphate buffered saline (PBS). The cells were plated on the dishes, allowed to become attached and then cultured in the same way as cells on gel.

Measurement of number of cell nuclei. (A) For cells cultured on collagen gel: The culture medium on collagen gel was removed, and the gel was solubilized with NCA with gentle shaking at $37^{\circ} \mathrm{C}$ for $30 \mathrm{~min}$ with the aid of Low-Profile Rocker (Bellco Glass, Inc, ,Vineland, N.J.); NCA was prepared by diluting the viscous solution of Nikkol BO-10TX with hot water with stirring and adjusted to a concentration of $0.07 \%$ $(\mathrm{v} / \mathrm{v})$ in $0.1 \mathrm{M}$ citric acid. The cell suspension in the solubilized gel was supplemented with NCA $(1 \mathrm{ml})$ and transferred to plastic test tubes with a plastic pipette. The dishes were washed with NCA ( $2 \mathrm{ml})$, and the washing solutions were combined with the suspension. The cells and/or nuclei were precipitated by centrifugation at $450 \times \mathrm{g}$ for $5 \mathrm{~min}$ at room temperature, and resuspended with NCA $(2 \mathrm{ml})$ with a vibrator. The resulting suspension was incubated for cell lysis for 7 $\min$ at $37^{\circ} \mathrm{C}$ in a water bath with continuous shaking. The nuclei were collected by centrifugation at $450 \times \mathrm{g}$ for $5 \mathrm{~min}$, suspended in cold $0.1 \mathrm{M}$ citric acid $(2-4 \mathrm{ml})$ and kept at $0-5^{\circ} \mathrm{C}$ during the assay. They were stable in this solution for at least $48 \mathrm{~h}$ at $0-5^{\circ} \mathrm{C}$, giving a similar score initially and after 2 days. The number of nuclei was counted in a hemocytometer and in some cases with a Coulter Counter, and values are presented as means \pm S.D. for triplicate dishes. -(B) For cells cultured on collagen-coated plastic: The culture medium was removed, and the cells were detached from the plastic surface by incubation with NCA ( $2 \mathrm{ml}$ ) for $10 \mathrm{~min}$ at $37^{\circ} \mathrm{C}$ with gentle shaking. The resulting suspension of cells and cell nuclei was supplemented with NCA $(1 \mathrm{ml})$, transferred to plastic test tubes and submitted to the same procedure for isolation of nuclei as in (A). - (C) For freshly isolated cells: Cells in $\alpha$ MEM ( $2 \mathrm{ml}$ ) were collected by centrifugation at $450 \times \mathrm{g}$ for $5 \mathrm{~min}$ and then resuspended in NCA $(2 \mathrm{ml})$ with a vibrator. The resulting suspension was incubated for cell lysis as in (A).

Analysis of size distribution of isolated cell nuclei. The size of nuclei was analyzed in a Coulter Counter (model ZM) connected with a channel analyzer (Channelyzer model 256) (Coulter Electronics, Inc). Cell nuclei in $0.1 \mathrm{M}$ citric acid were analyzed at $0.5 \mathrm{~mA}$ with attenuation 16 and preset gain 2 with an aperture tube of $50 \mu \mathrm{m}$ diameter, and size was calibrated with latex microspheres of $5.11 \mu \mathrm{m}$ diameter.

Assay of lactate dehydrogenase ( $\mathrm{LDH}$ ) activity in hepatocytes on collagen gel. The culture medium was aspirated, and cultured hepatocytes were washed with PBS $(1 \mathrm{ml})$ and then lysed with $0.07 \%$ Nikkol BO-10TX in PBS $(1 \mathrm{ml})$ with gentle shaking at $37^{\circ} \mathrm{C}$ for $20 \mathrm{~min}$ on a Low-Profile Rocker.
The detergent solution containing the cell lysate was transferred to a test tube, and used for assay of enzyme activity. As a control, PBS $(1 \mathrm{ml})$ without the detergent was used for the cell lysis procedure. The reaction mixture $(1 \mathrm{ml})$ for the assay contained $50 \mathrm{mM}$ lactate, $2 \mathrm{mM} \mathrm{NAD}, 0.025 \%$ nitrotetrazolium blue, $0.1 \%$ bovine serum albumin, $40 \mathrm{mM}$ Tris- $\mathrm{HCl}$ buffer (pH 7.5) and 5 units of diaphorases, the activities of which were determined in a reaction mixture composed of $0.1 \mathrm{M}$ phosphate buffer $(\mathrm{pH} 8), 1 \mathrm{mM} \mathrm{NADH}, 0.025 \%$ nitrotetrazolium blue and $0.1 \%$ bovine serum albumin at $37^{\circ} \mathrm{C}$. $\mathrm{LDH}$ reaction was started by adding the lysate solution, continued for $20 \mathrm{~min}$ at $37^{\circ} \mathrm{C}$ and stopped by adding $2 \mathrm{ml}$ of 0.1 $\mathrm{M} \mathrm{HCl}$. The amount of the reduced form of nitrotetrazolium blue was determined by measuring the absorbance at $550 \mathrm{~nm}$; the amount of lysate added was adjusted to give an absorbance of less than 0.6. Units of these enzymes were calculated assuming a molar extinction coefficient of the reduced dye of $1.24 \times 10^{4}$, and one unit of these enzymes was defined as the amount that reduced $1 \mu \mathrm{mol}$ of the dye per min at $37^{\circ} \mathrm{C}$. The activity of the lysate is presented as total units in the detergent solution added for cell lysis.

Materials. Insulin and collagenase for cell isolation (type I) were from Sigma Chemical Co., St. Louis. $\alpha \mathrm{MEM}$ was from Flow Laboratories, Inc., Irvine (UK) and McLoan (USA). Dexamethazone was from Shering AG., Berlin. Nikkol BO-10TX (polyoxyethylene oleoyl ether, HLB: 10) was from Nikko Chemicals Co., Tokyo. Diaphorase (NADH: dye oxidoreductase) from Bacillus megaterium was obtained from Toyo Jozo Co., Shizuoka, Japan.

\section{RESULTS AND DISCUSSION}

During screening studies to find a good detergent for cell nuclei isolation we found that aqueous solutions of Nikkol BO-10TX at concentrations of $0.03-0.1 \%(\mathrm{v} / \mathrm{v})$ had potent activity for cell lysis at $37^{\circ} \mathrm{C}$ without damaging the nuclei and with less aggregation among them. The cell lytic activity is demonstrated in Table I in comparison with the activity of Triton X-100 under the

Table I. COMPARISON OF THE NUMBERS OF NUCLEI PREPARED FROM FRESHLY ISOLATED HEPATOCYTES BY CELL LYSIS WITH NIKKOL BO-10TX AND TRITON X-100.

\begin{tabular}{lcc}
\hline Detergent & $\begin{array}{c}\text { Number of the nuclei } \\
\text { recovered }\left(\times 10^{-6}\right)\end{array}$ & $\begin{array}{c}\text { Number of the cells } \\
\text { applied }\left(\times 10^{-6}\right)\end{array}$ \\
\hline Nikkol BO-10TX & $1.34 \pm 0.06$ & $1.19 \pm 0.07$ \\
Triton X-100 & $1.14 \pm 0.09$ & $1.19 \pm 0.07$ \\
\hline
\end{tabular}

Freshly isolated hepatocytes in $\alpha$ MEM were collected by centrifugation in test tubes. The cells were suspended and incubated with $2 \mathrm{ml}$ of $0.1 \%(\mathrm{v} / \mathrm{v})$ Nikkol BO-10TX or Triton X-100 in $0.1 \mathrm{M}$ citric acid for $2 \mathrm{~min}$ at $37^{\circ} \mathrm{C}$ under shaking. The suspensions were then stirred in a mixer for $2 \mathrm{~min}$ and centrifuged. Cell nuclei in the precipitates were suspended in PBS (4 ml) for measurement of their numbers in a hemocytometer. Values are means $\pm S$.D for triplicate test tubes. Other experimental conditions were as described in the text. 
same conditions as those in a previous report (2). The detergent shows higher recovery of the nuclei from freshly isolated hepatocytes than Triton X-100. In standard conditions it was used at $0.07 \%$ in $0.1 \mathrm{M}$ citric acid. The numbers of nuclei prepared from freshly isolated cells with the detergent solution were counted in a hemocytometer and compared with those of the cells from which the nuclei were isolated. The values for nuclei were proportional to those of the cells (Fig. 1), but the former were a little higher (ca. 10\%). This difference in the values was probably because about $20 \%$ of adult rat hepatocytes are polynuclear, mainly binuclear, cells $(6,7)$. To determine the proportionally between the numbers of cultured cells and their nuclei, we assayed the activity of LDH of the cells instead of their numbers because the numbers of cultured hepatocytes cannot be determined accurately. The enzyme is considered to be a representative cytosolic enzyme liberated from damaged cells, and in a previous study its leakage from and trypan blue dye incursion into hepatocytes were reported to be of comparable sensitivity in evaluating cell survival (8). If it is assumed that viable hepatocytes cul-

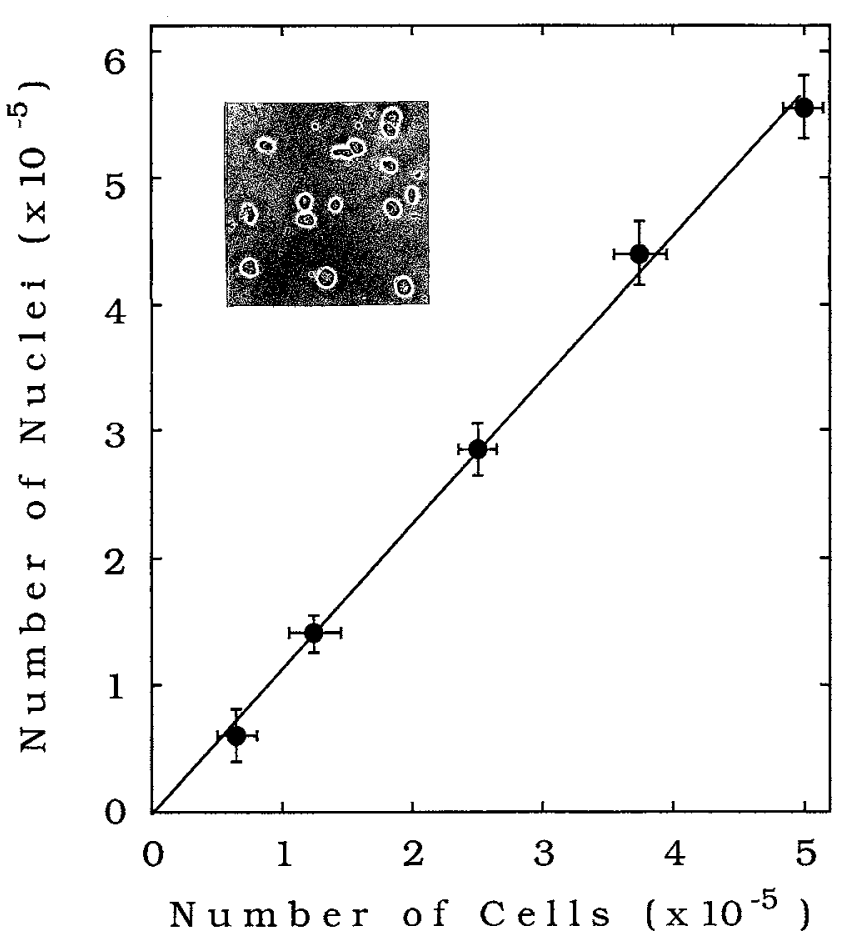

Fig. 1. Proportionality between number of freshly isolated hepatocytes and that of their nuclei assayed with NCA. Various numbers of cells in $\alpha$ MEM were collected by centrifugation in test tubes and cell nuclei were isolated from them. The numbers of cells and their nuclei were determined in a hemocytometer. Other experimental conditions were as described in the text. Values are means \pm S.D. for triplicate test tubes. (Inset): Phase-contrast micrograph of nuclei from freshly isolated cells. Magnification, $\times 150$. tured for the same period under the same conditions have the same LDH activity per a cell nucleus in each of their cell bodies, then the total activity of intracellular LDH may be proportional to the total number of nuclei of viable cells. In this study the enzyme activities of freshly isolated hepatocytes were proportional to the numbers of their nuclei (Fig. 2). Similarly, the enzyme activities of cells attached to the gel in $3 \mathrm{~h}$ cultures were proportional to the numbers of their nuclei (Fig. 2); the reason we used culture on the gel is that it sustains survival of hepatocytes cultured in serum-free medium more than culture on collagen- or serum-coated dishes. Thus, the enzyme activities of freshly isolated cells and cells just after attachment were proportional to the numbers of their nuclei counted in a hemocytometer. Prior to further examination of proportionality between numbers of nuclei of long term cultured cells and their LDH activities, we tried to count the numbers with an elec-

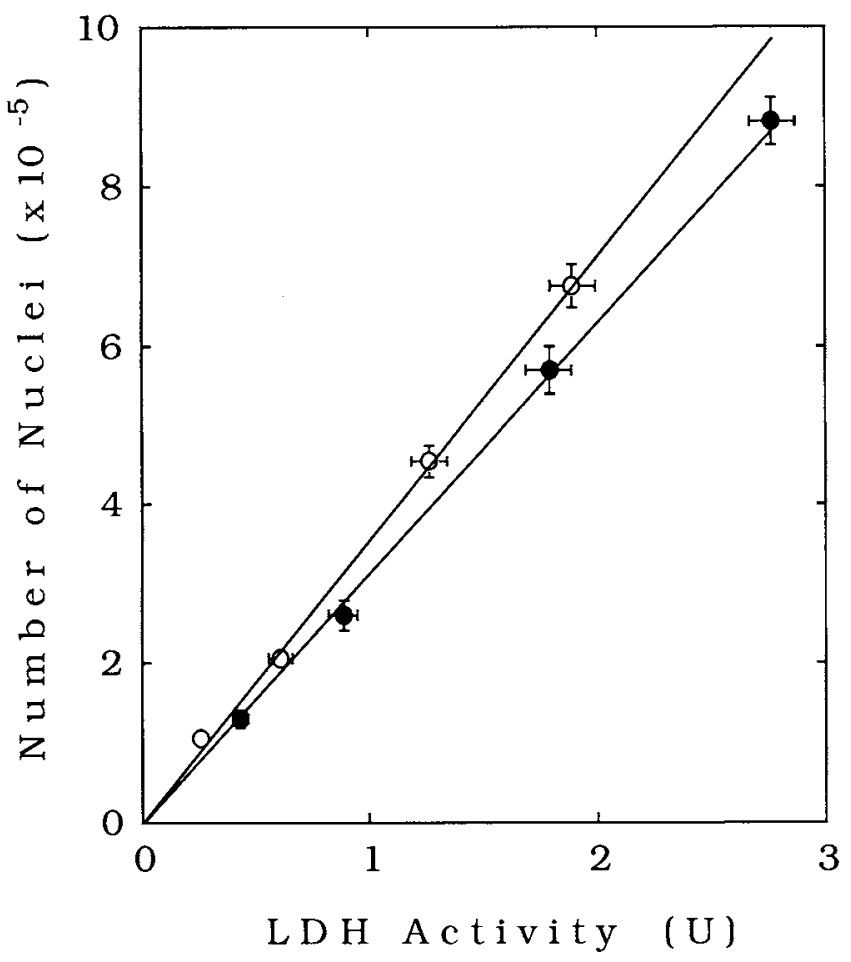

Fig. 2. Proportionality between numbers of nuclei of freshly isolated cells and cells cultured for $3 \mathrm{~h}$ after plating on collagen gel and LDH activities of their lysate. Various numbers of freshly isolated cells in $\alpha$ MEM were collected by centrifugation in test tubes and lysed with $0.07 \%$ Nikkol BO-10TX in PBS ( $2 \mathrm{ml})$ by incubation for $7 \mathrm{~min}$ for the assay of enzyme activity or Iysed with NCA $(2 \mathrm{ml})$ for the determination of cell nuclei. Numbers of cell nuclei of freshly isolated cells $(\bullet)$ and $3 \mathrm{~h}$ cultures $(O)$ were determined in a hemocytometer. Numbers of cells seeded on the gel were $1.1 \times 10^{5}, 2.2 \times 10^{5}, 4.4 \times 10^{5}$, $6.6 \times 10^{5}$, respectively. Other experimental conditions were as described in the text. Values are means \pm S.D. for triplicate test tubes. $\mathrm{U}$, units. 

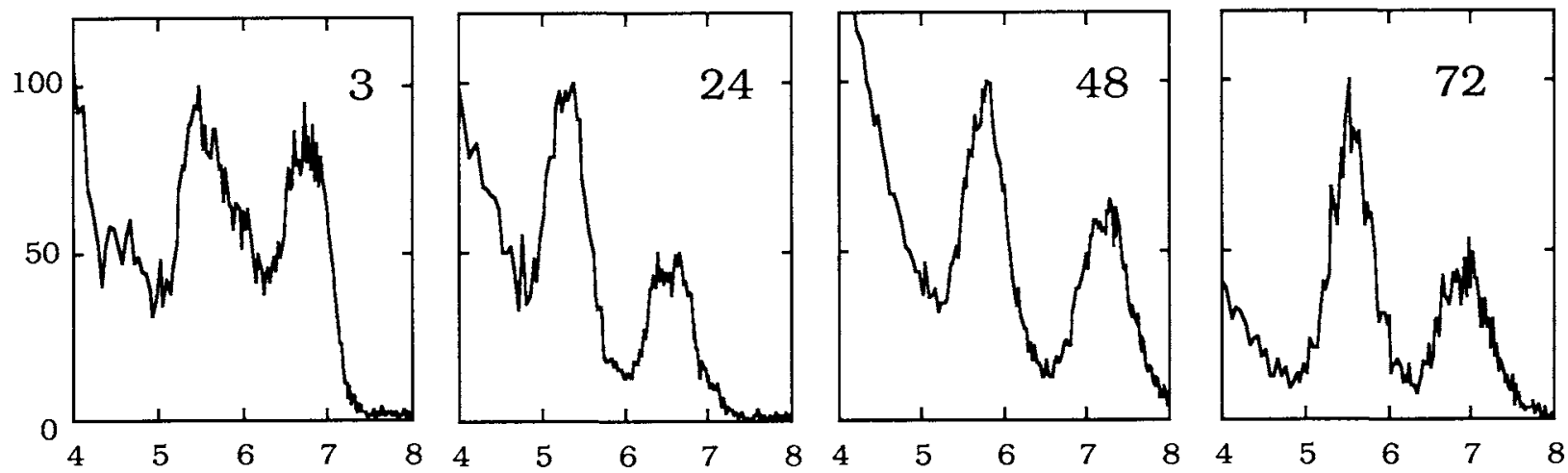

\section{Particle Diameter $(\mu \mathrm{m})$}

Fig. 3. Size analysis of isolated cell nuclei from cultures on collagen gel at $3 \mathrm{~h}, 24 \mathrm{~h}, 48 \mathrm{~h}$, and $72 \mathrm{~h}$ after plating. Samples of $6.1 \times 10^{5}(3 \mathrm{~h})$, $5.5 \times 10^{5}(24 \mathrm{~h}), 5.2 \times 10^{5}(48 \mathrm{~h})$ and $4.6 \times 10^{5}(72 \mathrm{~h})$ cell nuclei were analysed in the counter. Other experimental conditioins were as described in the text.

tronic particle counter, because in studies involving many cultures, counting nuclei with a hemocytometer is laborious and time consuming. As a trial, we analyzed the distribution of the size of isolated nuclei with a parti-

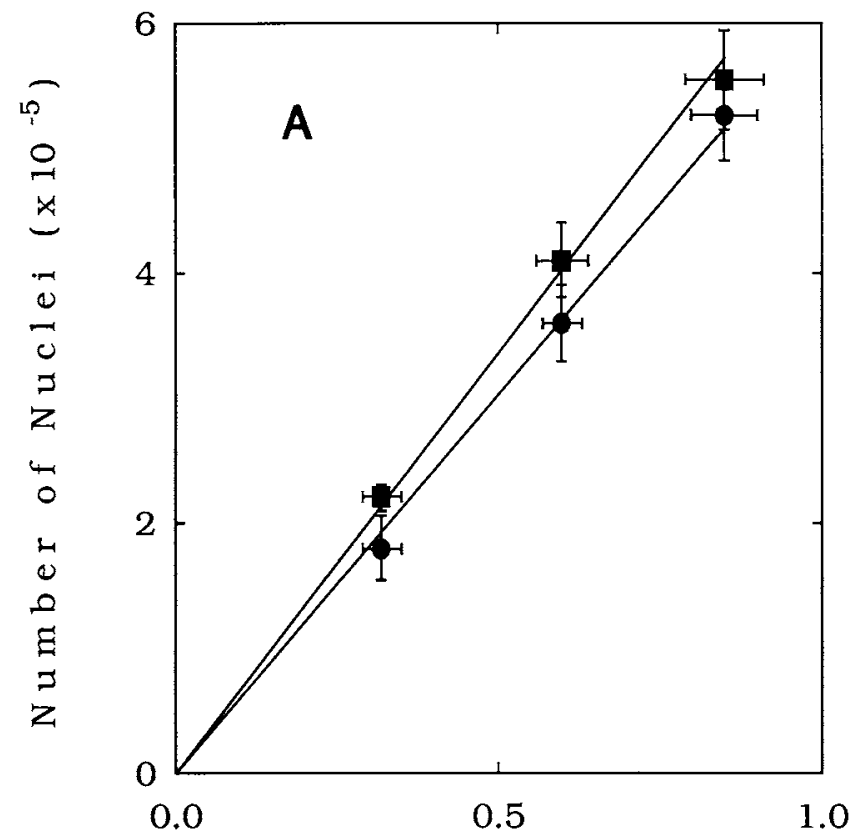

L D H A c ivity (U) cle analyzer, Coulter Channelyzer Model 256. The distributions of particle sizes of nuclei isolated after culture for $3 \mathrm{~h}, 24 \mathrm{~h}, 48 \mathrm{~h}$, and $72 \mathrm{~h}$ showed two main peaks (Fig. 3). Hepatocytes of adult rats (7-8 weeks old) are re-

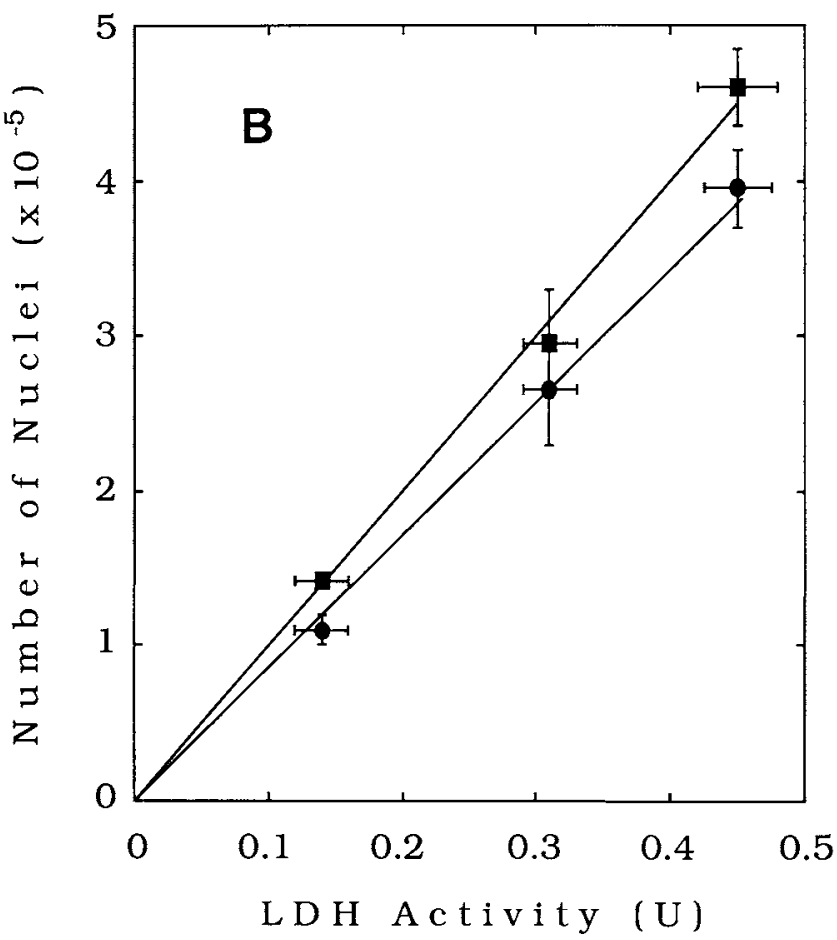

Fig. 4. Proportionalities between numbers of cell nuclei and LDH activities of lysates of $24 \mathrm{~h}$ (A) and $72 \mathrm{~h}$ (B) cultures on collagen gel. Numbers were determined in a hemocytometer $(\bullet)$ or a Coulter Counter $(\boldsymbol{\bullet})$. The lower threshold was set at 4.857 and the upper threshold at 7.693 for $24 \mathrm{~h}$ cultures and 8.000 for $72 \mathrm{~h}$ cultures. Numbers of cells seeded were $2 \times 10^{5}, 4 \times 10^{5}, 6 \times 10^{5}$, respectively. Other experimental conditions were as described in the text. $\mathrm{U}$, unit. 
ported to include four main types of cells, mononuclear diploid and tetraploid cells, and binuclear diploid and tetraploid cells (6). The percentages of diploid and tetraploid cells were about 33-35 and 64-65, respectively. One peak of smaller size and another peak of larger size in Fig. 3 are, therefore, suggested to correspond to populations of diploid and tetraploid cells, respectively. For cell nuclei in $3 \mathrm{~h}, 24 \mathrm{~h}$, and $72 \mathrm{~h}$ cultures, the bottoms of the first trough were at about 4.86 $\mu \mathrm{m}$ and those in $48 \mathrm{~h}$ cultures were at about $5.18 \mu \mathrm{m}$. The bottom values, set as lower threshold values, reflect the size of isolated cell nuclei. The highest value, in $48 \mathrm{~h}$ cultures, decreased with time during further culture towards the values of $3 \mathrm{~h}$ or $24 \mathrm{~h}$ cultures. The upper threshold value was set at the foot of the second peak, about $8.00 \mu \mathrm{m}$. At this setting, the counter responded to isolated cell nuclei selectively. The scores of $24 \mathrm{~h}$ and $72 \mathrm{~h}$ cultures with the instrument were parallel to the scores with a hemocytometer, although they were slightly higher. Both scores were proportional to the enzyme activities of cultures at various cell densities, in spite of the rapid decrease in enzyme activity during culture (Fig. 4A, B). The decrease in the specific activity (the enzyme activity/unit number of the nuclei) with time in culture is due neither to enzyme leakage from viable cells nor increase of the number of dead cells that still are attached but retain their nuclei after losing their cytosolic components, but to alterations in degradation and/or synthesis rate of the enzyme in viable hepatocytes (9) as in the cases of many other enzymes and cytochromes in the cells cultured under conventional long term culture conditions.

This method could also be used to quantify nuclei of hepatocytes cultured on collagen-coated plastic by the procedures described in Materials and Methods (data not shown).

\section{REFERENCES}

1. MCGowan, J.A. (1986). Hepatocyte proliferation in culture. In Isolated and Cultured Hepatocytes (A. Guillouzo and C. Guguen-Guillouzo eds.). John Libbey Eurotext Ltd./INSERM, London-Paris, pp13-38.

2. Nakamura, T., Tomita, Y., and Ichihara, A. (1983). Density-dependent growth control of adult rat hepatocytes in primary culture. J. Biochem., 94: 1029-1035.

3. SEGLEN, P.O. (1976). Preparation of isolated rat liver cells. In Methods in Cell Biology (D. Prescott, Ed.), Vol. 13, Academic Press, New York, pp29-83.

4. Yang, J., Richards, J., Bowman, P., Guzman, R., Enami, J., MCCormick, K., Hamamoto, S., Pitelka, D., and Nandi, S. (1979). Sustained growth and three dimensional organization of primary mammary tumor epithelial cells embedded in collagen gels. Proc. Natl. Acad. Sci. USA, 76: 3401-3415.

5. Elsdale, T. and BARD, J. (1972). Collagen substrata for studies on cell behavior. J. Cell Biol., 54:626-637.

6. JaMES, J., Schopman, M., and DelfGaAuw, P. (1966). The nuclear pattern of the parenchymal cells of the liver after partial hepatectomy. Exp. Cell Res., 42: 375-379.

7. Gomez-Lechon, M.J., Barbera, E., Gil, R., and Baguena, J. (1981). Evolutive changes of ploidy and polynucleation in adult rat hepatocytes in culture. Cell. Mol. Biol., 27: 695-701.

8. Jauregui, H.O., Hayner, N.T., Driscoll, J.L., WilliamsHolland, R., Lipsky, M.H., and Galletti, P.M. (1981). Trypan blue dye uptake and lactate dehydrogenase in adult rat hepatocytes-freshly isolated cells, cell suspensions, and primary monolayer cultures. In Vitro, 17: 1100-1110.

9. Marceat, N., Nokl, M., and Deschenes, J. (1982). Growth and functional activities of neonatal and adult rat hepatocytes cultured on fibronectin coated substratum in serum-free medium. In Vitro, 18: 1-11.

(Received for publication, November 2, 1991

and in revised form, April 17, 1991) 